\title{
Typification of Names in Nine Species of Arctotis (Asteraceae, Arctotideae) from the Succulent Karoo, South Africa
}

\author{
Robert J. McKenzie* and Nigel P. Barker \\ Molecular Ecology and Systematics Group, Department of Botany, Rhodes University, P.O. Box \\ 94, Grahamstown, 6140, South Africa.*Author for correspondence: r.mckenzie@ru.ac.za
}

ABstract. In preparation for the treatment of Arctotis L. (Asteraceae) in the upcoming Conspectus of the Trans-Cape Succulent Karoo Flora of South Africa, the typification of names and synonymy for nine Arctotis species that occur within the Succulent Karoo region, South Africa, are clarified. The author citation for A. argentea is corrected from Thunb. to A. argentea Aiton, and the lectotype is selected. In addition, lectotypes are designated for A. auriculata Jacq., A. campanulata DC., A. campanulata var. puberula DC., A. canescens DC., A. cineraria Jacq., A. cuprea Jacq., A. denudata Thunb., A. diffusa Thunb., A. fastuosa Jacq., A. flaccida Jacq., A. flammea Jacq., A. glabrata Jacq., A. laevis Thunb., A. leucanthemoides Jacq., A. maximilianii Schltr. ex Beauverd, A. pusilla DC., A. revoluta Jacq., A. rosea Jacq., A. squarrosa Jacq., A. venidioides DC., and Venidium aureum DC.

Key words: Arctotideae, Arctotidinae, Arctotis, Asteraceae, Compositae, South Africa.

Arctotis L. is the largest genus in the subtribe Arctotidinae, comprising approximately 60 to 70 species, and is widely distributed in southern Africa (Karis et al., 2009). The main center of taxonomic diversity of the genus is in the winter rainfall region of southern Africa. The taxonomy of Arctotis is especially chaotic. Some of the many taxonomic and nomenclatural problems have been resolved (McKenzie et al., 2006, 2008a, b; McKenzie \& Barker, 2007), but many names are still in need of typification. In preparation for the treatment of Arctotis in the upcoming Conspectus of the Trans-Cape Succulent Karoo Flora of South Africa (Snijman, in prep.), we herein clarify the synonymy and typification of names for nine Arctotis species that occur within the geographic area of southern Africa defined by Jürgens (1991) as the Succulent Karoo region. This region approximately corresponds to the part of the winter rainfall region that experiences the greatest summer aridity.

\section{LECTOTYPIFICATION OF ARCTOTIS ARGENTEA}

The name Arctotis argentea is usually attributed to Thunberg (1799). However, the name was validly published by Aiton (1789), who recorded the introduction of the species to the Royal Botanic Gardens, Kew, by Francis Masson in 1774. Masson accompanied Thunberg on collecting expeditions into the interior of the Cape colony in 1773 and 1774 (Gunn \& Codd, 1981). Although the descriptions for new names published by Aiton (1789) were prepared mainly by D. Solander and edited and amended by J. C. Dryander (Stafleu \& Cowan, 1976), under Article 46.7 of the International Code of Botanical Nomenclature (ICBN; McNeill et al., 2006) the name A. argentea must be attributed to Aiton.

A sheet in the Herbarium of the Natural History Museum, London (BM), is annotated in pencil "Arctotis argentea, Thb." and a label is attached bearing the inscription "Hort. Kew. 1777-Sem. E Cap. bon. Spei." Thus the specimen was prepared from material cultivated at Kew, and because its preparation post-dates the recorded introduction of $A$. argentea to Kew in 1774 and precedes publication of the description in Aiton (1789), this sheet is suitable for designation as the lectotype for A. argentea. The specimen is consistent with the morphological descriptions of Aiton (1789) and Thunberg (1799).

Arctotis argentea Aiton, Hort. Kew. 3: 273. 1789. TYPE: [South Africa.] Cape of Good Hope: Hort. Kew. Sem. E Cap. bon. spei [Hortus Kewensis semen e Capite bonae spei], 1777, s. coll. (lectotype, designated here, BM).

\section{LECTOTYPIFICATION OF ARCTOTIS AURICULATA}

Arctotis auriculata Jacq. is a robust, showy species from the Namaqualand region of northwestern South Africa. The species was described by Jacquin (1797). A single sheet (W 0006633) in the Naturhistorisches Museum Herbarium, Vienna (W), formerly in the Jacquin Herbarium, is annotated as A. auriculata and was designated the lectotype of this name on the sheet by Tycho Norlindh in 1980, but the typification was never published. The material agrees with the description and illustration in Jacquin (1797) and is herein formally designated the lectotype of $A$. auriculata Jacq. 
The name Arctotis flammea Jacq., published by Jacquin (1809), is a synonym of A. auriculata. However, no original material formerly in the Jacquin Herbarium has been located. Therefore, the illustration of A. flammea in Jacquin (1809), which agrees with Jacquin's description in all important features, is designated the lectotype of A. flammea.

Arctotis auriculata Jacq., Pl. Rar. Hort. Schoenbr. 2: 22, tab. 169. 1797. TYPE: [South Africa.] Hort. Schönbr. [Hortus Schoenbrunnensis], s.d., s. coll. (lectotype, designated here, W).

Arctotis flammea Jacq., Fragm. Bot. 41, tab. 47. 1809, syn. nov. TYPE: "Arctotis flammea" in Jacquin, Fragm. Bot., tab. 47. 1809 (lectotype, designated here, Jacquin, 1809: tab. 47).

\section{LECTOTYPIFICATION OF ARCTOTIS CAMPANULATA}

De Candolle (1838) described Arctotis campanulata DC., of which he distinguished two varieties (A. campanulata $\alpha$ subtomentosa DC. and $\beta$ puberula DC.). De Candolle did not list the corresponding autonym (A. campanulata var. campanulata). Under Article 26.2 of the ICBN (McNeill et al., 2006), since no type was indicated for A. campanulata DC., both varietal names were validly published. Under Article 26.3 , the valid publication of the varietal names automatically established the autonym (A. campanulata var. campanulata). The species $A$. campanulata requires lectotypification from among the specimens cited for each variety, which are therefore syntypes of A. campanulata.

De Candolle (1838: 485) stated that for both varieties he examined material collected by Drège in "Klein Namaqualand." In G-DC, two plants from the gathering Drège 6162 are mounted on a sheet labeled "Arctotis campanulata $\alpha$ subtomentosa," and on a separate sheet a single plant of the gathering Drège 2749 is labeled "Arctotis campanulata $\beta$ puberula." Duplicate sheets of Drège 2749 and 6162 are lodged in the Herbarium of the Muséum national d'Histoire naturelle, Paris (P). Additional material annotated as each variety, collected by Drège but lacking collector's numbers, are lodged in the Herbarium in G, Kew Herbarium (K), Missouri Botanical Garden Herbarium (MO), and the National Herbarium, Pretoria (PRE).

De Candolle (1838) distinguished the two varieties based on leaf pubescence and leaf lobe apex shape. Although Arctotis campanulata has been recognized in most subsequent treatments, its morphological characterization and discrimination from A. acaulis are problematic, and in herbaria the name has been applied to specimens belonging to several species. Arctotis acaulis is a very polymorphic species, varying particularly in leaf shape and dissection, and leaf and involucral bract pubescence. An investigation of the entire A. acaulis species complex is in progress. Pending the outcome of this investigation, the taxonomic recognition of A. campanulata is retained.

The duplicate of Drège 2749 in G-DC is herein designated the lectotype for Arctotis campanulata var. puberula. In morphology A. campanulata var. puberula is dubiously distinct from A. acaulis L. and might ultimately be placed in synonymy of that name, whereas A. campanulata var. subtomentosa is more disparate in morphology and appears to be specifically distinct from A. acaulis. Therefore, with nomenclatural stability in mind, the sheet Drège 6162 in G-DC is selected as the lectotype of A. campanulata DC.

On isolectotype sheets in $\mathrm{P}$, the provenance of Drège 2749 is stated to be Mierenkasteel, the farm now known as Meerhofkasteel located southwest of Bitterfontein, Western Cape (Gunn \& Codd, 1981), and the origin of Drège 6162 is specified as Haazenkraalsrivier. The collector's numbers 2749 and 6162 were not specified by Drège (1843), but he recorded collecting A. campanulata from "Haazenkraalsrivier, am Fluss und auf der Höhe daselbst," 600-760 m, "zwischen Uitkomst und Geelbekskraal," 600-900 m, and "bei Mierenkasteel, karrooartige Höhe," 300-600 m (Drège, 1843: 94, 96).

Arctotis campanulata DC., Prodr. 6: 485. 1838. Arctotis campanulata var. subtomentosa DC., Prodr. 6: 485. 1838, syn. nov. TYPE: South Africa. Northern Cape: Haazenkraalsrivier, 450600 m, 24 Aug. 1830, J. F. Drège 6162 (lectotype, designated here, G-DC; isotypes, P).

Aretotis campanulata var. puberula DC., Prodr. 6: 485. 1838. TYPE: South Africa. Western Cape: "bei Mierenkasteel," 300-600 m, 6 Aug. 1830, J. F. Drège 2749 (lectotype, designated here, GDC; isotypes, $\mathrm{P}$ ).

\section{LeCTOTYPIFICATION OF ARCTOTIS CANESCENS AND A. DIFFUSA}

De Candolle (1838) described Arctotis canescens DC. from two gatherings by Drège: Drège 671 from the Kamdeboberg and Drège 6161 from the Khamiesberg. The gatherings are of two distinct Arctotis species. The Drège 671 gathering was of the species previously named by Thunberg (1799) as A. diffusa Thunb. The Drège 6161 specimen is of a species not formally linked to a name previously.

Arctotis canescens and A. diffusa are readily distinguishable based on morphology and ecology (R. J. McKenzie, unpublished). A sheet in the Thunberg Herbarium (UPS-THUNB 20766), annotat- 
ed "Arctotis diffusa" and consistent with Thunberg's (1799) description, is designated herein as the lectotype of A. diffusa. Designation of Drège 671 as the lectotype of $A$. canescens would result in the placement of the name as a synonym of $A$. diffusa and require publication of a new name for the species represented by Drège 6161. Therefore, Drège 6161 is herein designated as the lectotype of $A$. canescens.

Arctotis canescens DC., Prod. 6: 485. 1838. TYPE: South Africa. Northern Cape: Kamiesberg, Roodeberg, Gydokap, s.d., J. F. Drège 6161 (lectotype, designated here, G-DC).

Aretotis diffusa Thunb., Arctotis: 9. 1799. TYPE: South Africa. "Promontorio bonae spei Africes," s.d., C. P. Thunberg s.n. (lectotype, designated here, UPS-THUNB).

\section{Lectotypification and Synonymy of ARctotis FAStuosa}

Arctotis fastuosa Jacq. is one of the major components of the famous spring-flowering annual Namaqualand daisies. The species was described by Jacquin (1797) from material cultivated in the gardens of the Schönbrunn Palace in Vienna. The original provenance of the plants was stated as "ex Promontorium bonae spei." One sheet formerly in the Jacquin Herbarium annotated as A. fastuosa is lodged at W and can be considered as the lectotype. The species varies greatly in size and leaf morphology and pubescence, but possesses distinctive achenes (see McKenzie et al., 2005). In the present study, four additional names were confirmed to be based on specimens of $A$. fastuosa, namely A. maximilianii Schltr. ex Beauverd, A. mirabilis Dümmer, Venidium aureum DC., and V. wyleyi Harv. Hoffmann (1910: 313) listed the names "A. Wybi (Harv.) O. Hoffm.Venidium Wybi Harv., l.c., p. 463," which was clearly intended to be $V$. wyleyi of Harvey (1865) and Hoffmann's new combination A. wyleyi; this can be treated as a typographic error requiring correction rather than Hoffmann (1910) publishing a new name.

Arctotis fastuosa Jacq., Pl. Rar. Hort. Schoenbr. 2: 20, tab. 166. 1797. Venidium fastuosum (Jacq.) Stapf, Bot. Mag. 152: tab. 9127. 1928. TYPE: [South Africa.] Hort. Schönbr. [Hortus Schoenbrunnensis], s.d., s. coll. (lectotype, designated here, W).

Venidium aureum DC., Prodr. 6: 494. 1838. Arctotis aurea (DC.) Beauverd, Bull. Soc. Bot. Genève, Sér. 2, 7: 44. 1915, non Arctotis aurea Burm. f., 1768, nom. illeg. TYPE: South Africa. Northern Cape: "zwischen Zwartdoornrivier und Groenrivier," 12 Aug. 1830, J. F. Drège 2739 (lectotype, designated here, G-DC; isotypes, P).
Venidium wyleyi Harv. in Harv. \& Sond., Fl. Cap. 3: 463. 1865. Arctotis wyleyi (Harv.) O. Hoffm., Ann. Nat. Hofmus. Wien 24: 313. 1910, as "wybi." TYPE: South Africa. Namaqualand, s.d., A. Wyley s.n. (holotype, TCD).

Arctotis mirabilis Dümmer, J. Roy. Hort. Soc. 40: 81. 1914. TYPE: South Africa. Little Namaqualand: Klipfontein, May 1902, E. Foxwell s.n. (holotype, K).

Arctotis maximilianii Schltr. ex Beauverd, Bull. Soc. Bot. Genève, Ser. 2, 7: 49. 1915. TYPE: South Africa. Namaqualand: Zabies, 12 July 1897, M. Schlechter s.n. (lectotype, designated here, K; isotypes, BR, HBG, P).

\section{Lectotypification and Synonymy of Arctotis Flaccida}

Arctotis flaccida Jacq. and A. leucanthemoides Jacq. were described by Jacquin (1797) from plants with an annual life history cultivated in the gardens of the Schönbrunn Palace in Vienna. The original provenance of the plants was stated to be "ex Promontorium bonae spei” (Jacquin, 1797: 19). Two sheets formerly in the Jacquin Herbarium annotated as A. flaccida and A. leucanthemoides, respectively, are lodged in $\mathrm{W}$ and can be considered as the respective lectotypes. Close examination of the specimens, focusing on the leaf morphology and arrangement, particularly that of the upper leaves, and immature achene and pappus morphology proved that the two names apply to the same species. The name A. flaccida is an appropriate allusion to the thin, precociously wilting nature of the leaves of this species and, consequently, this name is here selected as the valid name for the species.

De Candolle (1838) described two species, Arctotis pusilla DC. and A. venidioides DC., based on two separate Drège gatherings from the Olifantrivier area in the Western Cape. Previous authors have shown uncertainty in applying the two names but, based on the above-mentioned morphological features and the specimens' provenances, the names clearly apply to the same species as the names A. flaccida and A. leucanthemoides. The name A. pusilla was applied to a young plant that had a shortly caulescent habit and predominantly rosulate leaves. In contrast, the names A. flaccida, A. leucanthemoides, and A. venidioides were based on older plants in which lateral flowering stems with elongated internodes had developed.

A further name, Arctotis gowerae E. Phillips, which was based on plants grown from seeds collected in the Vanrhynsdorp district (Phillips, 1927), also applies to the same taxon and is herein placed in synonymy of $A$. flaccida. Arctotis gowerae has previously been considered to be a synonym of A. fastuosa, but differs from that species in leaf morphology and arrangement and the presence of a pappus of rudimentary scales. The holotype of A. gowerae is a single flowering lateral branch; the robust size reflects its horticultural origin.

Beyers (2000) placed Arctotis semipapposa (DC.) Beauverd as a synonym of A. flaccida without 
comment, but such a treatment is erroneous (McKenzie et al., 2008b).

Arctotis flaceida Jacq., Pl. Rar. Hort. Schoenbr. 2: 19, tab. 163. 1797. TYPE: [South Africa.] Hort. Schönbr. [Hortus Schoenbrunnensis], s.d., s. coll. (lectotype, designated here, W).

Arctotis leucanthemoides Jacq., Pl. Rar. Hort. Schoenbr. 2: 19, tab. 164. 1797, syn. nov. Ursinia leucanthemoides (Jacq.) Poir., Encycl. 8: 258. 1808, as "leucanthemifolia." Lycotis leucanthemoides (Jacq.) Hoffmanns., Verz. Pfl.-Nachtr. 2: 99. 1826. TYPE: [South Africa.] Hort. Schönbr. [Hortus Schoenbrunnensis], s.d., s. coll. (lectotype, designated here, W).

Arctotis pusilla DC., Prodr. 6: 489. 1838, syn. nov. TYPE: South Africa. Western Cape: "bei Olifantrivier, auf karrooartigen Höhen," under 1000 ft., s.d., J. F. Drège 2740 (lectotype, designated here, G-DC).

Arctotis venidioides DC., Prodr. 6: 489. 1838, syn. nov. TYPE: South Africa. Western Cape: "Olifantrivier, Ebenezar, auf steinigen, trocknen (karrooartigen) Hügeln," under 500 ft., s.d., J. F. Drège 6164 (lectotype, designated here, G-DC; isotypes, P).

Arctotis gowerae E. Phillips, Fl. Pl. South Africa 7: tab. 241. 1927, syn. nov. TYPE: South Africa. Western Cape: "Vanrhynsdorp dist., grown at the Division of Botany from seeds supplied by Mrs E. Rood," June 1924, E. Phillips 6036 (holotype, PRE).

\section{Lectotypification and Synonymy of ARctotis Revoluta}

The species generally known as Arctotis revoluta Jacq. is a widespread element of the A. aspera L. species complex and is distributed in Namaqualand and the Western Cape. The complex is morphologically diverse and taxonomically difficult, with a number of the forms receiving names at the species and variety levels. Resolution of taxa within the complex is one focus of an ongoing investigation. In the interim, forms with often secondarily pinnatisect leaves with narrow pinnae and revolute margins, and a distinctly shrubby, erect habit, are treated as a distinct species, A. revoluta, and names placed in its synonymy are herein typified. The leaf pubescence is extremely variable, but always includes a dense covering of short glandular trichomes, and may also bear moderately dense gray woolly tomentum and/or scabrid multiseptate trichomes. It must be noted that the name A. aspera var. undulata P. J. Bergius and the combination A. undulata (P. J. Bergius) Gaertn. may apply to this taxon and, if correct, would have nomenclatural priority over the name A. revoluta.

Four names published by Jacquin (1797, 1798), namely Arctotis cineraria Jacq., A. cuprea Jacq., A. glabrata Jacq., and A. squarrosa Jacq., are here treated as conspecific and synonyms of $A$. revoluta. Specimens labeled as A. cuprea, A. glabrata, and A. squarrosa, formerly in the Jacquin Herbarium and prepared from material cultivated in the gardens of the Schönbrunn Palace, are lodged in $\mathrm{W}$ and thus can be considered as the respective lectotypes. The sheet in W (W 0006631), annotated as A. cuprea Jacq., was designated the lectotype of $A$. cuprea by Tycho Norlindh in 1980, but the typification was never published. No such specimen labeled as A cineraria is extant in W. However, a specimen collected by J. Banks from "Capite bonae spei," formerly in the Jacquin Herbarium and annotated "Arctotis (aspera) cineraria Jacquin," is lodged in W. Jacquin (1797) gave no indication of seeing a gathering by Banks in the protologue of $A$. cineraria, so it cannot be assumed that the specimen formed part of the original material. In the absence of an extant specimen prepared from material cultivated in the Schönbrunn garden, the illustration of $A$. cineraria accompanying the protologue in Jacquin (1797) is herein designated the lectotype for A. cineraria.

Arctotis revoluta Jacq., Pl. Rar. Hort. Schoenbr. 2: 24, tab. 173. 1797. TYPE: [South Africa.] Hort. Schönbr. [Hortus Schoenbrunnensis], s.d., s. coll. (lectotype, designated here, W).

Arctotis cineraria Jacq., Pl. Rar. Hort. Schoenbr. 2: 24, tab. 174. 1797, syn. nov. TYPE: "Arctotis cineraria" in Jacquin, Pl. Rar. Hort. Schoenbr. 2: tab. 174. 1797 (lectotype, designated here, Jacquin, 1797: tab. 174).

Arctotis glabrata Jacq., Pl. Rar. Hort. Schoenbr. 2: 25, tab. 175. 1797, syn. nov. TYPE: [South Africa.] Hort. Schönbr. [Hortus Schoenbrunnensis], s.d., s. coll. (lectotype, designated here, W).

Arctotis cuprea Jacq., Pl. Rar. Hort. Schoenbr. 2: 25, tab. 176. 1797, syn. nov. Arctotis aspera var. cuprea (Jacq.) DC., Prodr. 6: 488. 1838. TYPE: [South Africa.] Hort. Schönbr. [Hortus Schoenbrunnensis], s.d., s. coll. (lectotype, designated here, W).

Arctotis squarrosa Jacq., Pl. Rar. Hort. Schoenbr. 2: 25, tab. 177. 1797, syn. nov. TYPE: [South Africa.] Hort. Schönbr. [Hortus Schoenbrunnensis], s.d., s. coll. (lectotype, designated here, W).

Arctotis laevis Thunb., Arctotis: 10. 1799, syn. nov. TYPE: [South Africa.] "Ex Promontorio bonae spei," s.d., C. P. Thunberg s.n. (lectotype, designated here, UPS-THUNB). Arctotis denudata Thunb., Arctotis: 14. 1799, syn. nov. TYPE: [South Africa.] "Ex Promontorio bonae spei," s.d., C. P. Thunberg s.n. (lectotype, designated here, UPS-THUNB).

Arctotis crispata Hutch., A Botanist in Southern Africa: 158. 1946, adnot., syn. nov. TYPE: South Africa. Northern Cape: Kamieskroon, 14 Oct. 1928, J. Hutchinson 845 (holotype, K; isotypes, BOL, PRE).

\section{LeCTOTYPIFICATION OF ARCTOTIS ROSEA}

Arctotis rosea Jacq. is a poorly known species described by Jacquin (1797) from a plant "ex Promontorio bonae spei" cultivated in the gardens of the Schönbrunn Palace, Vienna. The species is 
closely allied to $A$. acaulis, but differs in possessing a shortly caulescent habit, moderate woolly indumentum equally on the adaxial and abaxial leaf surfaces, an acute leaf apex, and a dark red ray floret limb. Mature achenes have not been seen. A sheet in W (W 0006615) formerly lodged in the Jacquin Herbarium and annotated "Arctotis rosea Jacq." agrees with the illustration and description of $A$. rosea published by Jacquin (1797) and is herein designated the lectotype of A. rosea.

Arctotis rosea Jacq., Pl. Rar. Hort. Schoenbr. 2: 18, tab. 162. 1797. TYPE: [South Africa.] Hort. Schönbr. [Hortus Schoenbrunnensis], s.d., s. coll. (lectotype, designated here, W).

Acknowledgments. The following herbaria are thanked for the loan of specimens or providing access to digital images of type specimens: Bergius Botanic Garden Herbarium, Stockholm; Bolus Herbarium, University of Cape Town, Cape Town; Compton Herbarium, Cape Town; Herbarium, Biozentrum Klein Flottbek und Botanischer Garten der Universität Hamburg, Hamburg; Herbarium, Department of Botany, Trinity College, Dublin; Herbarium, National Botanic Garden of Belgium, Meise; Herbarium, Natural History Museum, London; Herbarium, Naturhistorisches Museum, Vienna; Herbier, Muséum d'Historie naturelle-Conservatoire et Jardin botaniques Ville de Genève, Geneva; Herbier, Muséum national d'Histoire naturelle, Paris; Kew Herbarium, Royal Botanic Gardens, Kew; Missouri Botanical Garden Herbarium, St. Louis; and National Herbarium, South African National Biodiversity Institute, Pretoria. The Rhodes University Joint Research Committee and the National Research Foundation of South Africa (grant no. 2069059 to N. P. Barker and a postdoctoral fellowship to R. J. McKenzie) are thanked for financial support. Werner Greuter and an anonymous referee are thanked for comments that greatly improved the manuscript.

\section{Literature Cited}

Aiton, W. 1789. Hortus Kewensis; or, a Catalogue of the Plants Cultivated in the Royal Botanic Garden at Kew, Vol. 3. George Nicol, London.

Beyers, J. B. P. 2000. Arctotis. Pp. 303-306 in P. Goldblatt \& J. C. Manning (editors), Cape Plants: A Conspectus of the Cape Flora of South Africa. Strelitzia 9. National Botanical Institute, Pretoria; Missouri Botanical Garden, St. Louis.

Candolle, A. P. de. 1838. Prodromus systematis naturalis regni vegetabilis, Vol. 6. Treuttel \& Würtz, Paris.

Drège, J. F. 1843. Zwei pflanzengeographische Documente. Beigabe zur Flora 1843 Band II.
Gunn, M. \& L. E. Codd. 1981. Botanical Exploration of Southern Africa. Balkema, Cape Town.

Harvey, W. H. 1865. Compositae. Pp. 44-530 in W. H. Harvey \& O. W. Sonder (editors), Flora Capensis, Being a Systematic Description of the Plants of the Cape Colony, Caffraria and Port Natal, Vol. 3. L. Reeve, London.

Hoffmann, O. 1910. Compositae. Pp. 298-316 in A. Zahlbruckner (editor), Plantae Pentherianae: Aufzählung der von Dr. A. Penther und in seinem Auftrage von P. Krook in Südafrika gesammelten Pflanzen, pars IV. Ann. Naturhist. Hofmus. 24: 293-326.

Jacquin, N. J. von. 1797. Plantarum rariorum horti caesarei Schoenbrunnensis descriptiones et icones, Vol. 2. C. F. Wappler, Vienna; B. \& J. White, London; S. \& J. Luchtmans, Leiden.

— 1798. Plantarum rariorum horti caesarei Schoenbrunnensis descriptiones et icones, Vol. 3. C. F. Wappler, Vienna; B. \& J. White, London; S. \& J. Luchtmans, Leiden.

— 1809. Fragmenta botanica, figuris coloratis illustrata, ab anno 1800 ad annum 1809. M. A. Schmidt, Vienna.

Jürgens, N. 1991. A new approach to the Namib Region I: Phytogeographic subdivision. Vegetatio 97: 21-38.

Karis, P. O., V. A. Funk, R. J. McKenzie, N. P. Barker \& R. Chan. 2009. Arctotideae. Pp. 407-432 in V. A. Funk, A. Susanna, T. F. Stuessy \& R. J. Bayer (editors), Systematics, Evolution, and Biogeography of Compositae. International Association for Plant Taxonomy, Vienna.

McKenzie, R. J. \& N. P. Barker. 2007. Proposal to conserve the name Venidium semipapposum (Arctotis semipapposa) against Arctotis scabra (Asteraceae, Arctotideae). Taxon 56: 1300-1301.

— J. Samuel, E. M. Muller, A. K. W. Skinner \& N. P. Barker. 2005. Morphology of cypselae in subtribe Arctotidinae (Compositae-Arctotideae) and its taxonomic implications. Ann. Missouri Bot. Gard. 92: 569-594.

$\longrightarrow$, P. P. J. Herman \& N. P. Barker. 2006. Arctotis decurrens (Arctotideae), the correct name for A. merxmuelleri and A. scullyi. Bothalia 36: 171-173.

$\longrightarrow$, M. Hjertson \& N. P. Barker. 2008a. Typification of the name Arctotis lanata and those of some southern African Haplocarpha species (Asteraceae, Arctotideae). Taxon 57: 612-614.

$\longrightarrow$ - $—$ 2008b. Typification of Arctotis plantaginea and names in the Arctotis semipapposa species complex (Asteraceae, Arctotideae). Taxon 57: 1341-1346.

McNeill, J., F. R. Barrie, H. M. Burdet, V. Demoulin, D. L. Hawksworth, K. Marhold, D. H. Nicolson, J. Prado, P. C. Silva, J. E. Skog, J. H. Wiersema \& N. J. Turland (editors). 2006. International Code of Botanical Nomenclature (Vienna Code). Regnum Veg. 146.

Phillips, E. P. 1927. Arctotis gowerae. Fl. Pl. S. Africa 7: tab. 241.

Stafleu, F. A. \& R. S. Cowan. 1976. Taxonomic Literature: A Selective Guide to Botanical Publications and Collections with Dates, Commentaries and Types, 2nd ed., Vol. 1. Regnum Veg. 94. Bohn, Scheltema \& Holkema, Utrecht.

Thunberg, C. P. 1799. Arctotis, quam dissertatione botanice delineatum, venia exp. Ord. med. Upsal. praeside Carol. Pet. Thunberg...publicae censurae submittit. J. F. Edman, Upsalla. 


\section{$2 \mathrm{BHL}$ Biodiversity Heritage Library}

Mckenzie, Robert J and Barker, Nigel P. 2010. "Typification of Names in Nine Species of Arctotis (Asteraceae, Arctotideae) from the Succulent Karoo, South Africa." Novon a journal of botanical nomenclature from the Missouri Botanical Garden 20, 298-302.

View This Item Online: https://www.biodiversitylibrary.org/item/123332

Permalink: https://www.biodiversitylibrary.org/partpdf/122027

\section{Holding Institution}

Missouri Botanical Garden, Peter H. Raven Library

\section{Sponsored by}

Missouri Botanical Garden

\section{Copyright \& Reuse}

Copyright Status: Permission to digitize granted by rights holder Rights: https://www.biodiversitylibrary.org/permissions

This document was created from content at the Biodiversity Heritage Library, the world's largest open access digital library for biodiversity literature and archives. Visit BHL at https://www.biodiversitylibrary.org. 